\title{
Geochemical Investigation of Late Pre-Contact Ceramic Production Patterns in Northwest Alaska
}

Shelby L. Anderson (corresponding author) ${ }^{1}$, ashelby@pdx.edu

Matthew T. Boulanger ${ }^{2,3}$, mboulanger@smu.edu

Michael D. Glascock², glascockm@missouri.edu

R. Benjamin Perkins ${ }^{1}$, rperkins@pdx.edu

\begin{abstract}
Study of northwest Alaskan ceramic production and distribution patterns has the potential to provide new evidence of coastal hunter-gatherer mobility and social interaction in the late pre-contact period. This research is directed at characterizing potential clay sources and linking ceramic groups to raw-material source areas through instrumental neutron activation analysis (INAA) and modeling of possible clay and temper combinations. Results of INAA of 458 ceramic, 31 clay, and 28 possible temper specimens reinforces prior identification (Anderson et al., 2011) of three broad compositional groups. Though raw materials were collected over a large area, the clay specimens demonstrate remarkable geochemical homogeneity and fall within one of the established ceramic geochemical groups, Macrogroup 2. This suggests that potters may have added little to no mineral temper to the clays and also that what we have termed Macrogroup 2 ceramics were produced in the north and central areas of northwest Alaska. Group 1 and 3 ceramics may be evidence of pottery being brought into the region from elsewhere. Results indicate that ceramics circulated widely around the region and suggest the possibility of areas of greater production perhaps due to an abundance of clay or wood fuels needed for firing. This work lays the foundation for further exploring the cultural processes that underlie these distributions and provides insight into the complexities of hunter-gatherer ceramic production and distribution.
\end{abstract}

Keywords: hunter-gatherers; mobility; exchange; ceramics; neutron activation analysis; Arctic

\footnotetext{
${ }^{1}$ Portland State University, P.O. Box 751, Portland, OR 97207

${ }^{2}$ University of Missouri Research Reactor, 1513 Research Park Drive, Columbia, MO 65211

${ }^{3}$ Present Address: Department of Anthropology, Southern Methodist University, PO Box 750336, Dallas, TX 75275
} 
1.0 Introduction

Hunter-gatherer ceramic artifacts are relatively rare (see Jordan and Zvelebil, 2009 for

4 summary), but study of their distributions provides new insights into mobility, social interaction, and

5 technological organization (e.g., Eerkens, 2001, 2002, 2003; Eerkens et al., 2002; Simms et al., 1997).

6 Compositional analysis of North American Arctic ceramic technology presents an opportunity to study

7 coastal hunter-gatherer mobility and social interaction during the late Holocene, a period of significant

8 environmental and social change in the northwestern Arctic (Figure 1). Over at least the previous 3,000

9 years, coastal occupation increased and people developed specialized maritime tools and subsistence

10 strategies. There is evidence of increasing social difference as well as complex socioeconomic structures

11 that connected people across the region and beyond through extensive travel and trade. Compositional

12 analysis can help archaeologists study the changing geography of these networks over time, illuminating

13 how and why people maintained such extensive interaction networks during the Late Holocene. The

14 goal of this paper is to characterize potential clay sources and to link ceramic groups to raw-material

15 source areas through instrumental neutron activation analysis (INAA). The results of this work establish

16 a foundation for studying the cultural processes involved in Arctic ceramic distribution and the social

17 networks they represent. This work has broader implications for understanding hunter-gatherer

18 ceramic technology, mobility, and the role of social interaction in complex hunter-gatherer groups.

\subsection{Prior Work}

Prior to our 2011 pilot study (Anderson et al., 2011), it was not clear if the exchange of ceramic

22 artifacts was part of prehistoric distribution networks in northwest Alaska. While there is historic

23 evidence of ceramic trade, the antiquity of this practice was unknown. Ceramic technology was adopted

24 from western Beringia about 2,800 years ago (see Ackerman, 1982; Frink and Harry, 2008 for additional

25 summary). Early ceramics are thin, relatively hard, have a globular shape, and are decorated in

26 characteristic linear, check-stamp, or cord-marked styles. This early ceramic tradition is quite different

27 from later, post-1500 BP Arctic ceramics. Post-1500 BP ceramic vessels are thick, softer, cylindrical or

28 flower-pot shaped and often undecorated. Ceramics are much more abundant after 1500 BP. The rough

29 appearance of later ceramic cooking vessels suggests expedient production and local use, but a pilot

30 study that included INAA of 99 ceramic specimens from northwest Alaska established that hunter-

31 gatherer ceramics were part of distribution networks over at least the last 1,000 years (Anderson et al., 
32 2011). This work also demonstrated the potential of ceramic research for addressing questions about

33 Arctic hunter-gatherer lifeways. Questions remained, however, about the location of production areas

34 and the nature of interaction networks. Analysis of a larger sample of ceramics was needed. The study

35 presented here builds on the earlier pilot project by including a larger sample which also incorporates

36 raw clay and temper materials collected from across the region.

37

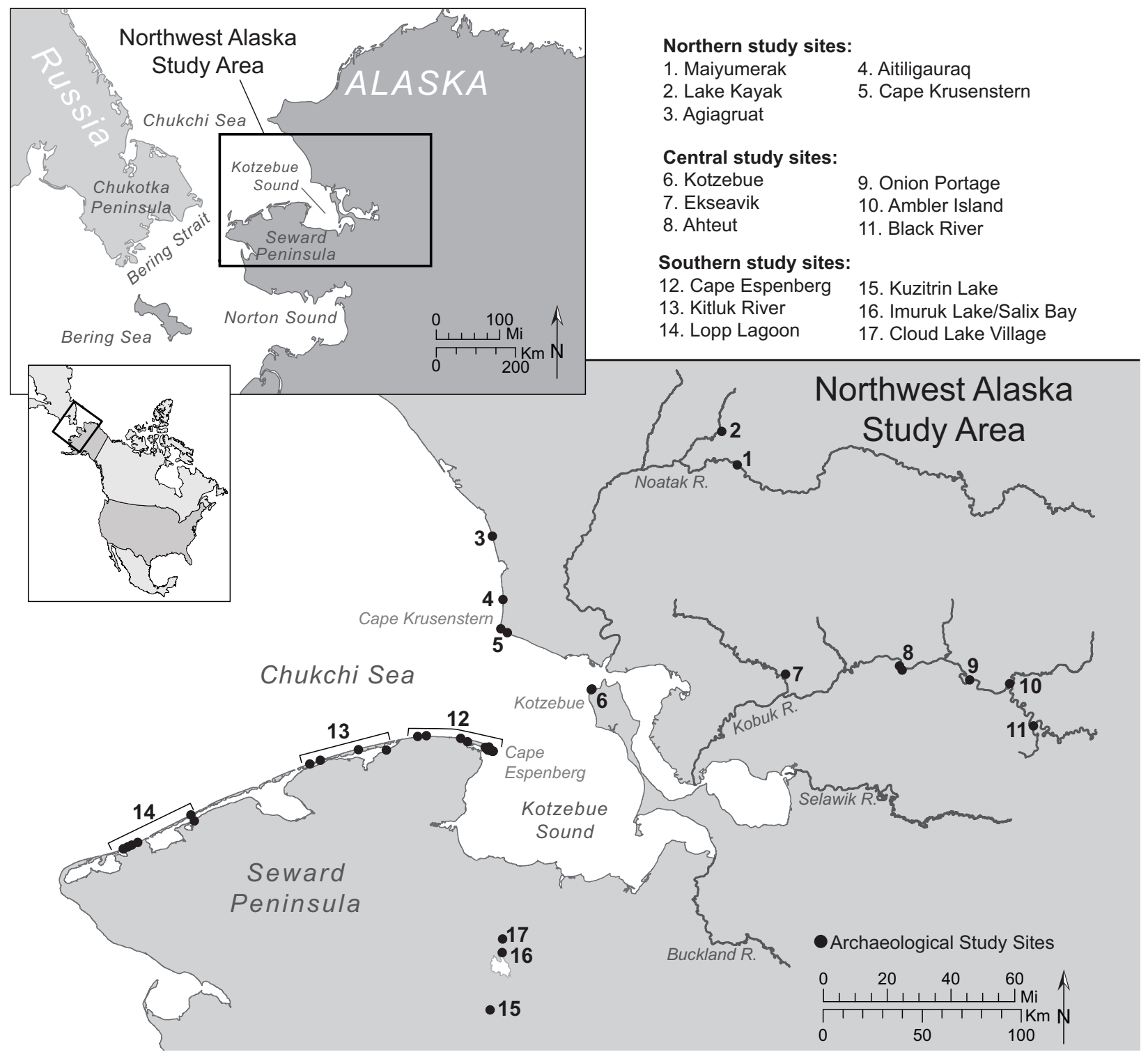

Figure 1. Map of study area with archaeological study site locations indicated. 


\section{$43 \quad 3.0$ Samples}

\section{$44 \quad 3.1$ Ceramics}

45 This study relies on existing ceramic collections from northwest Alaska. The advantage of this

46 approach is that it allows significant temporal and geographic expansion of the project. The

47 disadvantages of using museum collections include variation in sample sizes from sites available for

48 study, limited provenience and contextual information, and limited information on collection methods

49 in some cases. Information was most limited for collections made by Giddings in the 1940s and 50s at

50 Kotzebue and along the Kobuk River (Giddings, 1952), but the value of including these relatively large

51 collections from otherwise unstudied areas of northwest Alaska outweighed the disadvantages. A total

52 of 8,395 ceramic specimens from 17 sites spanning the study period (

53 Table 1) were classified according to various technological and decorative attributes using

54 standard ceramic analysis methods (e.g., Rice, 1987). A subsample of specimens for INAA was selected

55 from each site based on the nature and size of primary temper, exterior color, and exterior surface

56 treatment (Anderson, 2011). Rim sherds were preferentially selected for analysis to limit the potential

57 of sampling the same vessel twice. An additional 360 ceramic specimens were submitted for analysis by

58 neutron activation as part of this study, bringing the total sample to 458 specimens ${ }^{1}$.

\footnotetext{
${ }^{1}$ Specimen SLA 244, though submitted for analysis, was of insufficient mass for reliable analysis by neutron activation using standard University of Missouri Research Reactor procedures.
} 
Although study of ceramic production and distribution patterns is possible without direct

62 comparison to geological samples of clay from potential source areas, analyses of clays can aid in

63 connecting ceramic geochemical groups to production locales (Eerkens, 2002; Quinn et al., 2013).

64 Additionally, surveys directed at identifying raw materials for ceramic production can yield information

65 about the availability and suitability of clays at both local and regional scales. A clay survey was

66 conducted as part of this project to aid in identifying ceramic distribution patterns and to gain insight

67 into potters' choices during the production process. Survey design was informed by ethnographic data

68 on clay sources (Anderson, accepted), by available geologic information, and by logistical issues

69 associated with working in remote areas of northwest Alaska. Identification and sampling of reported

70 and possible sources near the archaeological study sites were priorities. Survey was conducted along

71 the Kobuk River and its tributaries, along the northern coast, and in several areas of the southern coast

72 and interior (Figure 2). A total of 40 clay specimens and 39 possible temper specimens were collected

73 during the survey, and two additional clay specimens were provided by colleagues. Of these, 28 temper

74 and 31 clay specimens were submitted for geochemical analysis (Table 3).

Collection methods and an in-depth discussion of survey results are detailed elsewhere

77 (Anderson, accepted); however, key findings of the survey that are important for interpreting these

78 geochemical analyses are as follows. First, clays suitable for making pottery are not universally available

79 across the study area. For example, few clay deposits appropriate for pottery making were identified in

80 the southern part of the study area. Second, there is considerable variability in clay quality and in the

81 nature and density of aplastic inclusions within a given geological deposit. Third, not all sources of clay

82 were used by Native Alaskan potters, despite being located in close proximity to archaeological sites. In

83 sum, these findings suggest that even though geological deposits of clay are widespread, access to

84 suitable or desirable clays may have been restricted by cultural factors such as the season of site

85 occupation, the extent of a particular group's territory, and the nature of intergroup relationships within

86 the region. 


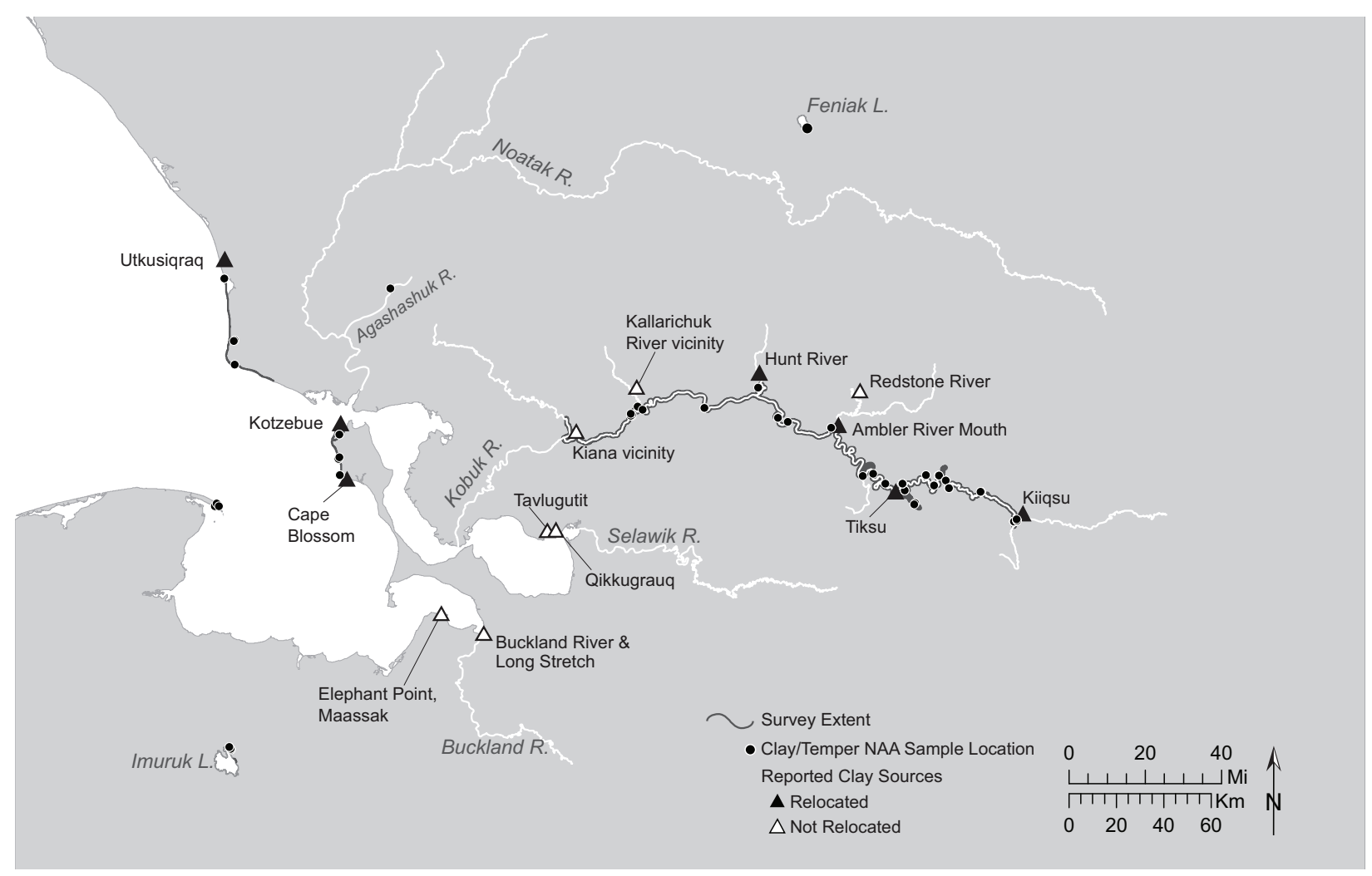

88 Figure 2. Reported sources and clay sampling locations. 
Table 1. Summary of Sites and Specimens Included in the Study (See Table 2 for Chronological Details)

\begin{tabular}{|c|c|c|c|c|}
\hline Site Name (Site \#) & $\begin{array}{l}\text { Analyzed Assemblage } \\
\text { Size* }\end{array}$ & NAA & $\begin{array}{l}\text { Chronological } \\
\text { Units }\end{array}$ & References \\
\hline Agiagruat (NOA 217) & 778 & 26 & II & Young, 2000 \\
\hline Ahteut (XBM 2,3) & 403 & 52 & II & Giddings, 1952; Shirar, 2011 \\
\hline Aitiligauraq (NOA 284) & 29 & 9 & IV & NPS, n.d. \\
\hline Ambler Island (AMR 2, 6) & 61 & 16 & III & Giddings, 1952; Shirar, 2011 \\
\hline \multirow[t]{6}{*}{ Black River (SHU 22) } & 19 & 5 & II & Giddings, 1952 \\
\hline & 7 & 4 & I & $\begin{array}{l}\text { Darwent et al., 2013; Harritt, 1994; Schaaf, 1988; } \\
\text { Unpublished Cape Espenberg Project Dates }\end{array}$ \\
\hline & 3899 & 63 & II & $\begin{array}{l}\text { Darwent et al., 2013; Harritt, 1994; Schaaf, 1988; } \\
\text { Unpublished Cape Espenberg Project Dates }\end{array}$ \\
\hline & 507 & 11 & III & $\begin{array}{l}\text { Darwent et al., 2013; Harritt, 1994; Schaaf, 1988; } \\
\text { Unpublished Cape Espenberg Project Dates }\end{array}$ \\
\hline & 409 & 18 & III-IV & $\begin{array}{l}\text { Darwent et al., 2013; Harritt, 1994; Schaaf, 1988; } \\
\text { Unpublished Cape Espenberg Project Dates }\end{array}$ \\
\hline & 2 & 1 & IV & Harritt, 1994; Schaaf, 1988 \\
\hline \multirow[t]{5}{*}{ Cape Espenberg (Multiple Sites) } & 27 & 2 & ii-iv & $\begin{array}{l}\text { Darwent et al., 2013; Harritt, 1994; Schaaf, 1988; } \\
\text { Unpublished Cape Espenberg Project Dates }\end{array}$ \\
\hline & 5 & 3 & I & Giddings and Anderson, 1986 \\
\hline & 69 & 27 & II & Giddings and Anderson, 1986 \\
\hline & 10 & 4 & II-III & Giddings and Anderson, 1986 \\
\hline & 98 & 4 & III & Giddings and Anderson, 1986 \\
\hline Cape Krusenstern (Multiple Sites) & 94 & 12 & II-IV & Giddings and Anderson, 1986 \\
\hline Cloud Lake Village (BEN 33) & 55 & 10 & III & Adams, 1977; Powers et al., 1975 \\
\hline Ekseavik (XBM 9) & 179 & 26 & II & Giddings, 1952; Shirar, 2011 \\
\hline Kitluk River (KTZ 145, 149) & 168 & 22 & IV & Harritt, 1994; Schaaf, 1988 \\
\hline Kotzebue (KTZ 31, 32) & 542 & 63 & III & Giddings, 1952 \\
\hline Kuzitrin (BEN 29) & 25 & 4 & III & Harritt, 1994; Powers et al., 1982; Schaaf, 1988 \\
\hline \multirow[t]{3}{*}{ Lake Kayak (MIS 32) } & 18 & 3 & III & Gilbert-Young, 2004; Shirar, 2011 \\
\hline & 4 & 4 & II & Harritt, 1994; Schaaf, 1988 \\
\hline & 1 & 1 & III & Harritt, 1994; Schaaf, 1988 \\
\hline \multirow[t]{3}{*}{ Lopp Lagoon (TEL 104) } & 53 & 7 & $\mathrm{ii}-\mathrm{iii}$ & Harritt, 1994; Schaaf, 1988 \\
\hline & 31 & 1 & ii-iii & Harritt, 1994; Schaaf, 1988 \\
\hline & 98 & 6 & III & Harritt, 1994; Schaaf, 1988 \\
\hline Lopp Lagoon (TEL 86) & 23 & 4 & II & Harritt, 1994; Schaaf, 1988 \\
\hline
\end{tabular}




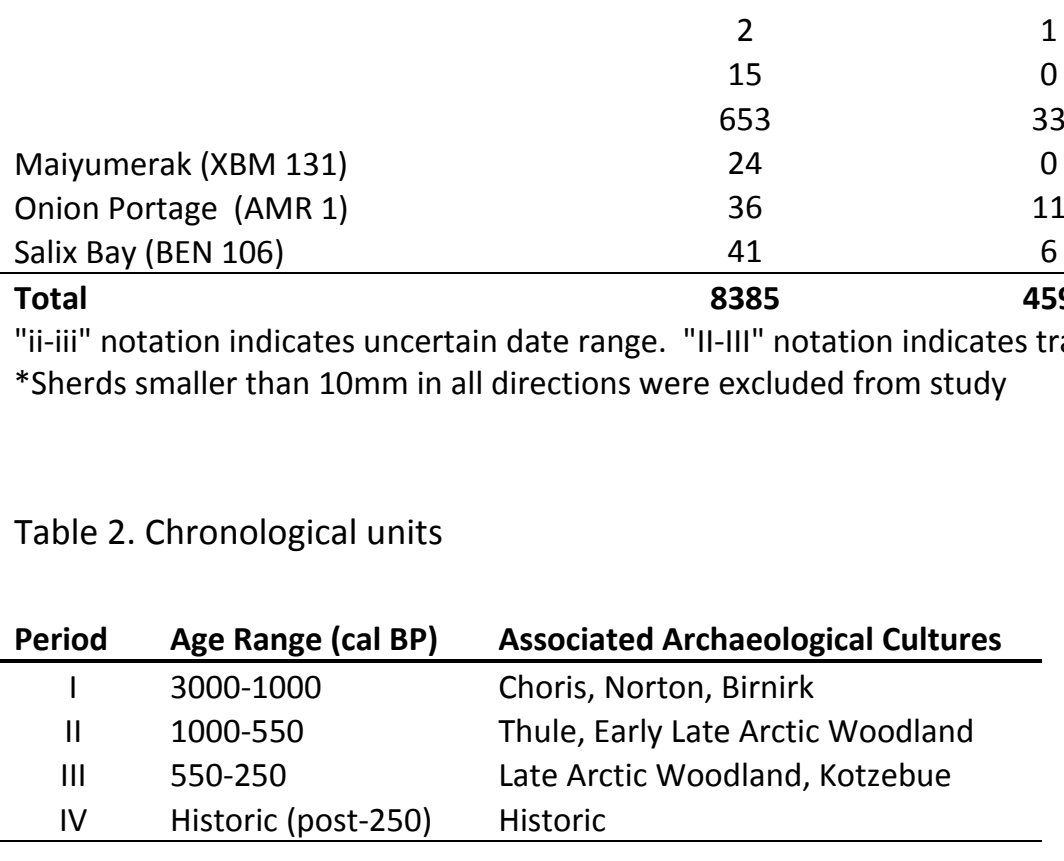


Table 3. Clay and Temper Samples Subjected to INAA

\begin{tabular}{|c|c|c|c|c|}
\hline Region & Sampling Location & $\begin{array}{l}\text { Sample } \\
\text { Type }\end{array}$ & Identifier & Deposit \\
\hline North & Cape Krusenstern & Temper & SLA429 & Beach \\
\hline North & Cape Krusenstern (North CAKR Lagoon) & Clay & SLA427 & Sedimentary - Glacial \\
\hline North & Cape Krusenstern (North CAKR Lagoon) & Temper & SLA428 & Beach \\
\hline North & Kotlik Lagoon & Clay & SLA364 & Sedimentary - Glacial \\
\hline North & Noatak River - Feniak Lake site (XHP 4) & Clay & SLA456 & Unknown \\
\hline Central & Aggie (tributary of Kobuk River) & Clay & SLA366 & Unknown \\
\hline Central & Hunt River (tributary of Kobuk River) & Temper & SLA451 & Beach \\
\hline Central & Kobuk River (Lower) & Clay & SLA392 & Unknown \\
\hline Central & Kobuk River (Lower) & Clay & SLA393 & Unknown \\
\hline Central & Kobuk River (Middle) - Ahteut site & Clay & SLA391 & Sedimentary - Glacial \\
\hline Central & Kobuk River (Middle) - Ahteut site & Temper & SLA452 & Beach \\
\hline Central & Kobuk River (Middle) - Ambler site & Clay & SLA389 & Sedimentary - Glacial \\
\hline Central & Kobuk River (Middle) - Onion Portage site & Clay & SLA390 & Sedimentary - Glacial \\
\hline Central & Kobuk River (Middle) - Onion Portage site & Temper & SLA450 & Beach \\
\hline Central & Kobuk River (Upper) & Clay & SLA382 & Sedimentary - Fluvial \\
\hline Central & Kobuk River (Upper) & Clay & SLA383 & Sedimentary - Glacial \\
\hline Central & Kobuk River (Upper) & Temper & SLA444 & Beach \\
\hline Central & Kobuk River (Upper) - Black River site & Temper & SLA449 & Beach \\
\hline Central & Kobuk River (Upper) - Cosmos Creek Mouth & Temper & SLA447 & Beach \\
\hline Central & River & Temper & SLA443 & Beach \\
\hline Central & Kobuk River (Upper) - Near Mauneluk River & Clay & SLA378 & Sedimentary - Glacial \\
\hline Central & Kobuk River (Upper) - Near Mauneluk River & Clay & SLA379 & Sedimentary - Glacial \\
\hline Central & Kobuk River (Upper) - Near Mauneluk River & Temper & SLA441 & Beach \\
\hline Central & Kobuk River (Upper) - Pah River Mouth & Clay & SLA376 & Sedimentary - Glacial \\
\hline Central & Kobuk River (Upper) - Pah River Mouth & Temper & SLA439 & Beach \\
\hline Central & Kobuk River (Upper) - Pah River Mouth & Temper & SLA440 & Beach \\
\hline Central & Kobuk River (Upper) - Pick River & Clay & SLA384 & Sedimentary - Alluvium/Fluvial \\
\hline Central & Kobuk River (Upper) - Pick River & Clay & SLA385 & Sedimentary - Alluvium/Fluvial \\
\hline Central & Kobuk River (Upper) - Pick River & Sand/Gravel & SLA445 & Beach \\
\hline Central & Kobuk River (Upper) - Shungnak & Clay & SLA386 & Sedimentary - Glacial \\
\hline Central & Kobuk River (Upper) - Shungnak & Clay & SLA387 & Sedimentary - Glacial \\
\hline Central & Kobuk River (Upper) - Shungnak & Temper & SLA446 & Beach \\
\hline Central & Kobuk River (Upper) - Shungnak River & Temper & SLA448 & Beach \\
\hline Central & Kotzebue-Cape Blossom & Clay & SLA369 & Sedimentary - Glacial \\
\hline
\end{tabular}




$\begin{array}{lllll}\text { Central } & \text { Kotzebue-Cape Blossom } & \text { Clay } & \text { SLA370 } & \text { Sedimentary - Glacial } \\ \text { Central } & \text { Kotzebue-Cape Blossom } & \text { Clay } & \text { SLA371 } & \text { Sedimentary - Glacial } \\ \text { Central } & \text { Kotzebue-Cape Blossom } & \text { Temper } & \text { SLA435 } & \text { Beach } \\ \text { Central } & \text { Kotzebue-Cape Blossom } & \text { Temper } & \text { SLA436 } & \text { Beach } \\ \text { South } & \text { Cape Espenberg site } & \text { Clay } & \text { SLA367 } & \text { Sedimentary - nearshore or glacial deposit } \\ \text { South } & \text { Cape Espenberg site } & \text { Temper } & \text { SLA431 } & \text { Beach } \\ \text { South } & \text { Cape Espenberg site } & \text { Temper } & \text { SLA432 } & \text { Dune } \\ \text { South } & \text { Cape Espenberg site } & \text { Temper } & \text { SLA433 } & \text { Beach } \\ \text { South } & \text { Imuruk Lake - Salix Bay site } & \text { Temper } & \text { SLA437 } & \text { Beach } \\ \text { South } & \text { Imuruk Lake } & \text { Clay } & \text { SLA372 } & \text { Residual } \\ \text { South } & \text { Imuruk Lake } & \text { Clay } & \text { SLA373 } & \text { Residual } \\ \text { South } & \text { Imuruk Lake } & \text { Clay } & \text { SLA375 } & \text { Residual } \\ \text { South } & \text { Imuruk Lake } & \text { Temper } & \text { SLA438 } & \text { Beach }\end{array}$

\section{$97 \quad 4.0$ Methods}

98 Analyses of the ceramic, clay, and temper specimens were performed at the University of

99 Missouri Research Reactor (MURR) by the Archaeometry Laboratory, and protocols for sample

100 preparation, irradiation, and gamma-ray spectroscopy followed established procedures (Glascock, 1992;

101 Glascock and Neff, 2003; Neff, 2000). The interpretation of compositional data obtained from the

102 analysis of archaeological materials is discussed in detail elsewhere (Baxter and Buck, 2000; Bieber et al.,

103 1976; Bishop and Neff, 1989; Glascock, 1992; Harbottle, 1976; Neff, 2000) and is not summarized here.

104 Statistical analyses employed for identification of ceramic and clay geochemical groups included

105 principal component analysis and Mahalanobis distance calculations. Compositional data generated for

106 clay and temper specimens were combined to model potential ceramic compositions following methods

107 outlined by Neff et al. (1988). 


\subsection{Results}

1115.1 Ceramics

112 Analyses of the additional 360 ceramic specimens reinforce our prior identification of three

113 broad compositional macrogroups (Anderson et al., 2011). Principal components analysis indicates that

114 greater than $90 \%$ of the cumulative variance in the 458 -specimen ceramic sample can be explained by

115 seven components (Table 4). The first principal component (PC) is positively loaded on $\mathrm{Cs}$, $\mathrm{Ta}$, and $\mathrm{Rb}$,

116 and negatively loaded on transition metals such as V, Co, and $\mathrm{Cr}$ (Figure 3). Subgroupings developed in

117 the pilot study were refined with this additional analysis; many of the outliers to Macrogroups 1 and 2

118 were successfully reassigned, and Subgroup 2e was entirely eliminated. The majority of specimens can

119 be assigned to the remaining groups and subgroups (Table 5). Ninety-five specimens (20.7\%) remain

120 unassigned to any compositional group. In compositional studies of this size and scope, this is not an

121 unreasonable number of unassignable specimens. They could represent ceramic products from exotic

122 or distant sources, or they could reflect sampling issues (e.g., local sources that are insufficiently

123 represented in the present sample).

124

125 


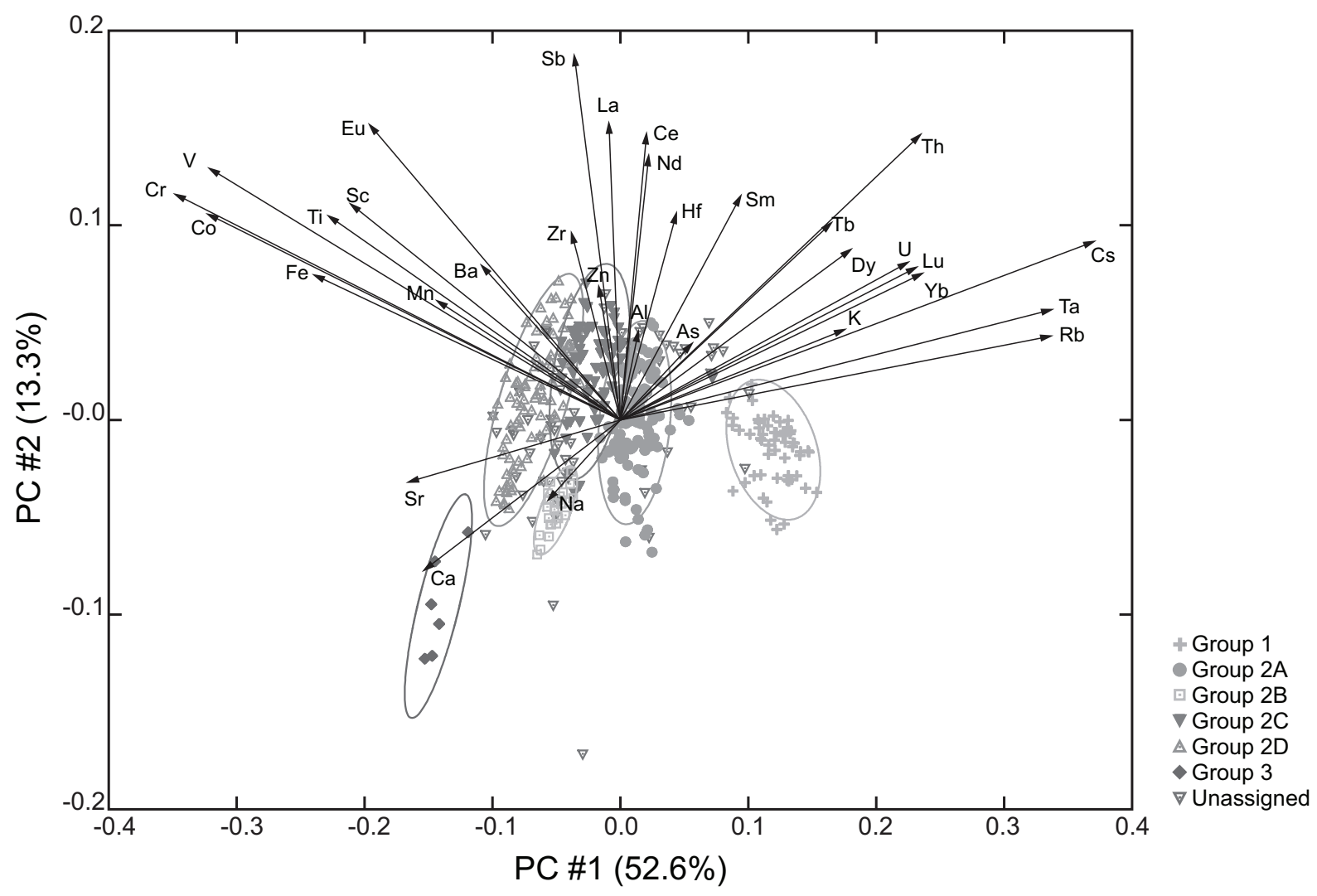

126

127 Figure 3. Principal component biplot showing compositional groups and unassigned specimens for the

128 northwestern Alaska ceramic dataset. Elemental loading vectors are shown and labeled. Ellipses are

129 drawn at the $90 \%$ confidence interval.

130

131 
132 Table 4. Principal Components Analysis of the Alaskan Ceramic Sample

\begin{tabular}{|c|c|c|c|c|c|c|c|}
\hline & PC1 & PC2 & PC3 & PC4 & PC5 & PC6 & PC7 \\
\hline \% Variance: & 52.643 & 13.29 & 10.652 & 5.327 & 4.187 & 2.145 & 1.865 \\
\hline $\begin{array}{l}\text { \% Cum. } \\
\text { Variance: }\end{array}$ & 52.643 & 65.933 & 76.585 & 81.911 & 86.098 & 88.244 & 90.109 \\
\hline Eigenvalues: & 2.053 & 0.518 & 0.415 & 0.208 & 0.163 & 0.084 & 0.073 \\
\hline Cs & 0.325 & 0.16 & 0.152 & -0.402 & -0.25 & 0.153 & 0.109 \\
\hline $\mathrm{Ta}$ & 0.296 & 0.099 & 0.321 & 0.213 & -0.086 & -0.079 & 0.208 \\
\hline$R b$ & 0.295 & 0.075 & 0.099 & -0.144 & -0.217 & -0.109 & 0.077 \\
\hline$Y b$ & 0.208 & 0.132 & 0.192 & 0.174 & 0.095 & -0.008 & 0.087 \\
\hline$T h$ & 0.206 & 0.256 & -0.269 & 0.035 & -0.076 & -0.135 & -0.062 \\
\hline Lu & 0.204 & 0.137 & 0.175 & 0.178 & 0.08 & -0.016 & 0.09 \\
\hline$U$ & 0.198 & 0.142 & -0.034 & -0.009 & 0.019 & -0.281 & 0.07 \\
\hline Dy & 0.159 & 0.154 & 0.117 & 0.182 & 0.089 & 0.004 & 0.045 \\
\hline$K$ & 0.155 & 0.082 & -0.025 & -0.116 & -0.275 & -0.075 & -0.083 \\
\hline$T b$ & 0.145 & 0.177 & 0.089 & 0.183 & 0.085 & -0.019 & 0.036 \\
\hline Sm & 0.083 & 0.202 & -0.032 & 0.151 & 0.037 & 0 & -0.015 \\
\hline As & 0.05 & 0.07 & 0.421 & -0.349 & 0.206 & -0.143 & -0.422 \\
\hline$H f$ & 0.039 & 0.187 & -0.077 & 0.081 & -0.078 & 0.15 & -0.017 \\
\hline$N d$ & 0.02 & 0.238 & -0.177 & 0.12 & -0.007 & 0.006 & -0.055 \\
\hline $\mathrm{Ce}$ & 0.018 & 0.258 & -0.213 & 0.097 & -0.008 & -0.042 & -0.051 \\
\hline$A l$ & 0.013 & 0.082 & 0.022 & -0.011 & -0.138 & 0.122 & -0.063 \\
\hline La & -0.008 & 0.267 & -0.253 & 0.073 & -0.04 & -0.038 & -0.052 \\
\hline$Z n$ & -0.015 & 0.121 & 0.058 & 0.074 & 0.16 & -0.247 & -0.196 \\
\hline$S b$ & -0.032 & 0.327 & 0.093 & -0.214 & 0.094 & 0.134 & -0.507 \\
\hline$Z r$ & -0.034 & 0.169 & -0.162 & 0.052 & -0.039 & 0.028 & 0.003 \\
\hline $\mathrm{Na}$ & -0.051 & -0.073 & 0.224 & 0.111 & -0.485 & 0.015 & 0.104 \\
\hline$B a$ & -0.096 & 0.14 & -0.288 & -0.242 & -0.159 & -0.405 & 0.095 \\
\hline$M n$ & -0.126 & 0.108 & 0.181 & 0.121 & 0.133 & -0.368 & 0.068 \\
\hline $\mathrm{Ca}$ & -0.136 & -0.135 & 0.186 & 0.434 & -0.194 & -0.309 & -0.32 \\
\hline$S r$ & -0.146 & -0.056 & 0.031 & -0.063 & -0.506 & -0.289 & -0.185 \\
\hline$E u$ & -0.172 & 0.265 & -0.089 & 0.08 & -0.079 & 0.107 & -0.016 \\
\hline Sc & -0.185 & 0.194 & 0.159 & -0.037 & -0.093 & 0.196 & 0.023 \\
\hline $\mathrm{Ti}$ & -0.201 & 0.184 & 0.11 & 0.154 & -0.149 & 0.251 & 0.052 \\
\hline $\mathrm{Fe}$ & -0.211 & 0.13 & 0.038 & 0.102 & 0.005 & 0.04 & -0.063 \\
\hline$V$ & -0.282 & 0.226 & 0.221 & -0.016 & -0.158 & 0.203 & 0.065 \\
\hline Co & -0.283 & 0.185 & 0.132 & -0.03 & 0.076 & -0.117 & 0.12 \\
\hline $\mathrm{Cr}$ & -0.305 & 0.203 & 0.152 & -0.272 & 0.156 & -0.255 & 0.479 \\
\hline
\end{tabular}

133 Note: The first seven PCs are shown, accounting for more than $90 \%$ of the cumulative variance in the 134 dataset. Strong elemental loading of individual components is shown in bold. 
Table 5. Ceramic Geochemical Group Assignments

\begin{tabular}{|c|c|c|c|c|c|c|c|c|c|}
\hline Region & Site Name & 1 & $2 a$ & $2 b$ & $2 c$ & $2 d$ & 3 & Unassigned & $\begin{array}{c}\text { Chronological } \\
\text { Unit }\end{array}$ \\
\hline \multirow{11}{*}{ North } & Agiagruat & 0 & 5 & 1 & 18 & 1 & 0 & 1 & II \\
\hline & Aitiligauraq & 9 & 0 & 0 & 0 & 0 & 0 & 0 & IV \\
\hline & Cape Krusenstern I & 0 & 0 & 0 & 0 & 0 & 0 & 3 & 1 \\
\hline & Cape Krusenstern II & 1 & 9 & 0 & 5 & 3 & 1 & 8 & II \\
\hline & Cape Krusenstern III & 4 & 0 & 0 & 0 & 0 & 0 & 0 & III \\
\hline & Cape Krusenstern II-III & 0 & 1 & 0 & 1 & 2 & 0 & 0 & II-III \\
\hline & Cape Krusenstern ii-iv & 0 & 2 & 0 & 1 & 1 & 1 & 5 & ii-iv \\
\hline & Cape Krusenstern II-IV & 0 & 0 & 0 & 1 & 0 & 0 & 1 & II-IV \\
\hline & Lake Kayak & 2 & 0 & 0 & 0 & 0 & 0 & 1 & IV \\
\hline & Maiyumerak III & 0 & 24 & 4 & 2 & 1 & 0 & 2 & III \\
\hline & Maiyumerak II & 0 & 1 & 0 & 0 & 0 & 0 & 0 & II \\
\hline \multirow{6}{*}{ Central } & Ahteut & 0 & 39 & 0 & 8 & 1 & 0 & 4 & II \\
\hline & Ambler Island & 3 & 0 & 1 & 5 & 1 & 4 & 2 & III \\
\hline & Black River & 4 & 0 & 0 & 0 & 0 & 0 & 1 & II \\
\hline & Ekseavik & 0 & 10 & 0 & 10 & 4 & 0 & 2 & II \\
\hline & Kotzebue & 8 & 15 & 15 & 5 & 3 & 0 & 17 & III \\
\hline & Onion Portage & 0 & 8 & 0 & 0 & 0 & 0 & 3 & III \\
\hline \multirow{10}{*}{ South } & Cape Espenberg I & 0 & 0 & 0 & 1 & 2 & 0 & 1 & 1 \\
\hline & Cape Espenberg II & 1 & 1 & 1 & 10 & 27 & 0 & 23 & II \\
\hline & Cape Espenberg III & 2 & 0 & 0 & 1 & 3 & 0 & 5 & III \\
\hline & Cape Espenberg III-IV & 7 & 0 & 0 & 0 & 7 & 0 & 3 & III-IV \\
\hline & Cape Espenberg ii-iv & 0 & 0 & 0 & 0 & 0 & 0 & 2 & ii-iv \\
\hline & Cape Espenberg IV & 1 & 0 & 0 & 0 & 0 & 0 & 0 & IV \\
\hline & Cloud Lake Village & 1 & 0 & 1 & 2 & 6 & 0 & 0 & III \\
\hline & Kitluk River (KTZ 145) & 3 & 0 & 2 & 1 & 14 & 0 & 2 & IV \\
\hline & Kuzitrin & 0 & 0 & 0 & 0 & 3 & 0 & 1 & III \\
\hline & Lopp Lagoon II & 5 & 0 & 0 & 0 & 2 & 0 & 0 & II \\
\hline
\end{tabular}




\begin{tabular}{lcccccccccc} 
Lopp Lagoon III & 4 & 0 & 0 & 0 & 1 & 0 & 2 & III \\
Lopp Lagoon ii-iii & 3 & 0 & 0 & 0 & 3 & 0 & 3 & ii-iii \\
Salix Bay & 0 & 0 & 0 & 0 & 3 & 0 & 3 & III \\
\hline & $\mathbf{5 8}$ & $\mathbf{1 1 5}$ & $\mathbf{2 5}$ & $\mathbf{7 1}$ & $\mathbf{8 8}$ & $\mathbf{6}$ & $\mathbf{9 5}$ & $\mathbf{4 5 8}$
\end{tabular}

"ii-iii" notation indicates uncertain date range versus II-III, which indicates transitional dates 
Eight specimens (Table 6) in the dataset are characterized by a significantly lower

139 concentration of Al relative to all other specimens $(\mu=1.62 \pm 0.77 \%)$. Of these, six specimens

140 (SLA024, 025, 67, 135, 139, 284) are enriched in transition metals $\mathrm{Cr}$ and $\mathrm{Co}$, as well as being

141 characterized by significant Al depletion. The concentrations of $\mathrm{Cr}(\mu=2160.4 \pm 347.7 \mathrm{ppm})$ and

142 Co $(\mu=76.7 \pm 3.9 \mathrm{ppm})$ are the highest in the entire dataset. When combined with significant

143 depletion in the rare earth elements (REEs) and alkali metals ( $\mathrm{Na}, \mathrm{K}, \mathrm{Rb}$, and $\mathrm{Cs}$ ), these chemical

144 characteristics are highly distinctive (Figure 4). Only two archaeological sites are represented by

145 these six specimens: Ambler Island $(n=4)$ and Cape Krusenstern $(n=2)$. Three of the four

146 specimens from Ambler Island are from the same house feature. Considering that the lowest

147 observed Al concentration in the sampled clays is 5.38\% (SLA366, collected from a tributary of

148 the Kobuk River), it is reasonable to conclude that none of the sampled clay sources were used

149 in the production of these sherds. Of the eight low Al specimens, two (SLA 356 and SLA 511)

150 may eventually form the basis for a new compositional group. These two specimens are also

151 depleted in Al, but their REE abundances and concentrations of transition metals are similar to

152 the majority of other ceramic specimens analyzed here.

153 


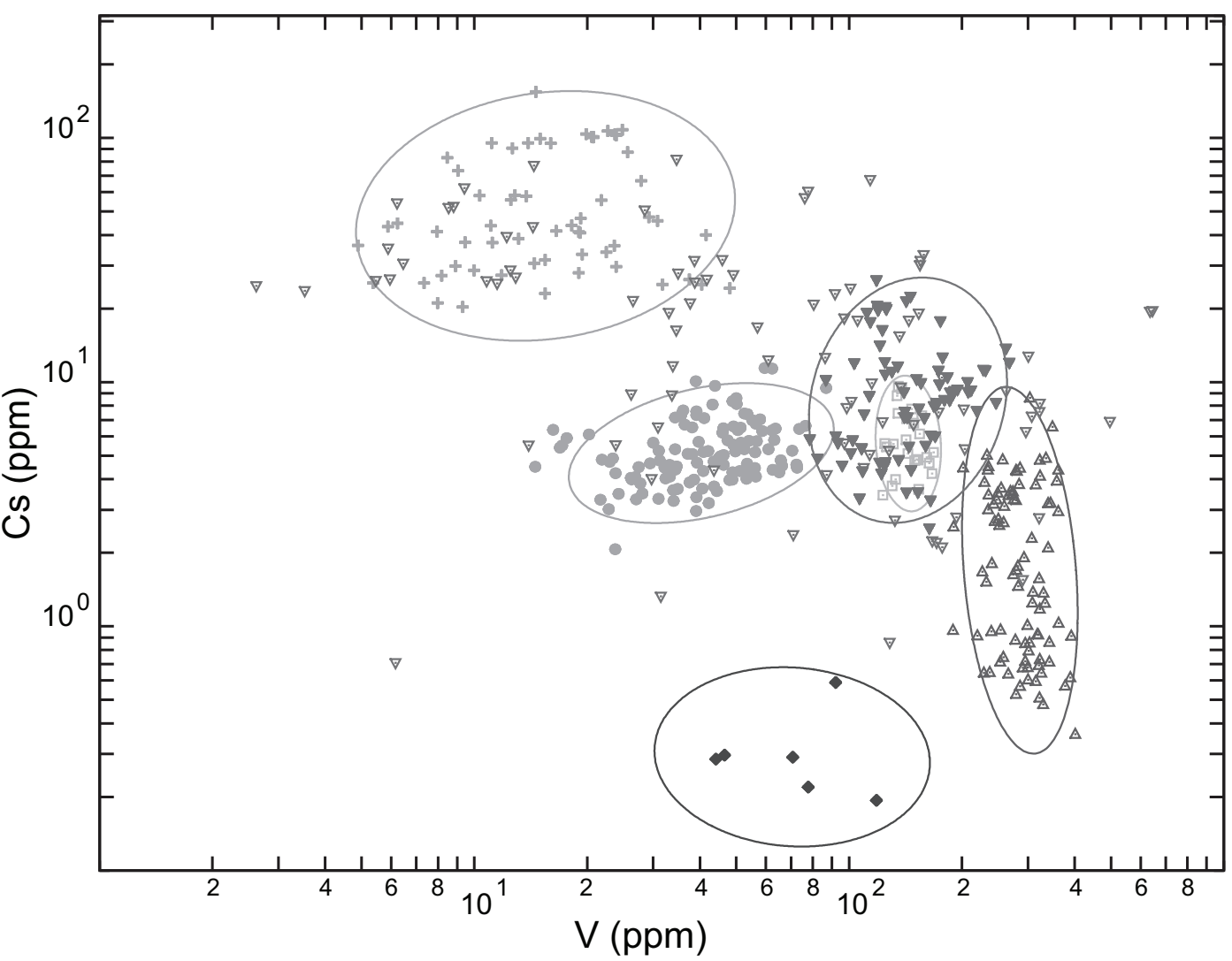

+ Group 1

- Group 2A

- Group 2B

$\checkmark$ Group 2C

$\triangle$ Group 2D

155

$\rightarrow$ Group 3
$\nabla$ Unassigned

156 Figure 4. Bivariate plot of Cs versus V concentrations in the northwestern Alaska ceramic

157 dataset. Ellipses are drawn at the $90 \%$ confidence interval.

158

159

160 
161 Table 6. Eight Specimens Comprising the Low-Al Compositional Group

\begin{tabular}{cc} 
ANID & Context \\
\hline SLA024 & Ambler Island, House 7 \\
SLA025 & Ambler Island, House 7 \\
SLA067 & Cape Krusenstern, House 1B \\
SLA135 & Ambler Island, House 7 \\
SLA139 & Ambler Island, House 10 \\
SLA284 & Cape Krusenstern, Surface Scatter 1B \\
SLA356 & Agiagruat, Feature 6 \\
SLA511 & Cape Espenberg, 7N 8E
\end{tabular}

162 Note that specimens SLA356 and SLA511 have significantly lower transition-metal abundances, and

163 therefore likely represent a different provenance or ceramic recipe.

166 All of the clay specimens analyzed here are geochemically most similar to Group $2 c$, with the 167 exception of SLA393 (collected in the lower Kobuk River region), which is most similar to Group 1682 2a (Figure 5). We used the geochemical data generated for clay and temper specimens in a 169 mixture model to generate compositional profiles that represent ceramic products produced 170 using each raw material. The goal of the modeling process was to explore how people may have 171 used the raw materials we collected during the raw-material survey. Potential tempering 172 materials (mineral grit and sand) were combined with clays from that same locality in $10 \%$ 173 increments from zero (pure clay) to $50 \%$ (half temper and half clay, by mass). Modeled ceramic 174 compositions were then projected against the various compositional groups proposed by 175 Anderson et al. (2011). Group-membership probabilities based on Mahalanobis distance using

17633 elemental abundances were calculated for each modeled ceramic composition

177 (Supplementary Information 1).

179 Results of this modeling process suggest that all of the clays and clay/temper mixtures are most 180 similar, in general, to our compositional Macrogroup 2, and specifically to Groups 2a and 2c.

181 None of the modeled ceramics produced compositions similar to Group 1 or to Group 3,

182 suggesting that these two compositional groups comprise pottery produced with resources that 183 were not sampled during the survey. Given the coverage of the survey, it is possible that both 184 of these compositional groups represent non-local ceramic artifacts. 
186 Several of the raw clays as well as the modeled ceramic compositions have very low

187 probabilities of belonging to any of the compositional groups we defined. Clays (and modeled

188 ceramics) from Ahteut and the lower Kobuk Valley are not strong statistical matches for any of

189 our groups, suggesting that these raw materials were likely not used for ceramic production.

190 Clays collected from Cape Espenberg have group-membership probabilities of effectively zero,

191 similarly indicating that they may not have been used prehistorically.

192

193 The ceramic-modeling results allow us to draw some preliminary conclusions regarding the

194 significance of our various compositional groups. Figure 6 shows the 11 different clay sources

195 projected against compositional groups, as well as the effects of adding $50 \%$ temper to each of

196 the clays (see also Table 7). In each instance, adding temper to raw clay results in compositions

197 more similar to those of ceramics placed within the Group 2 macrogroup, suggesting that some

198 of the chemical variation within the Group 2 subgroups is likely related to the kinds and

199 amounts of temper added to each product. Again, we note the dissimilarity of Group 1 and

200 Group 3 to any of the raw clays and to any of the modeled ceramics, suggesting that they were

201 produced using raw materials with fundamentally different chemical characteristics.

202

203 


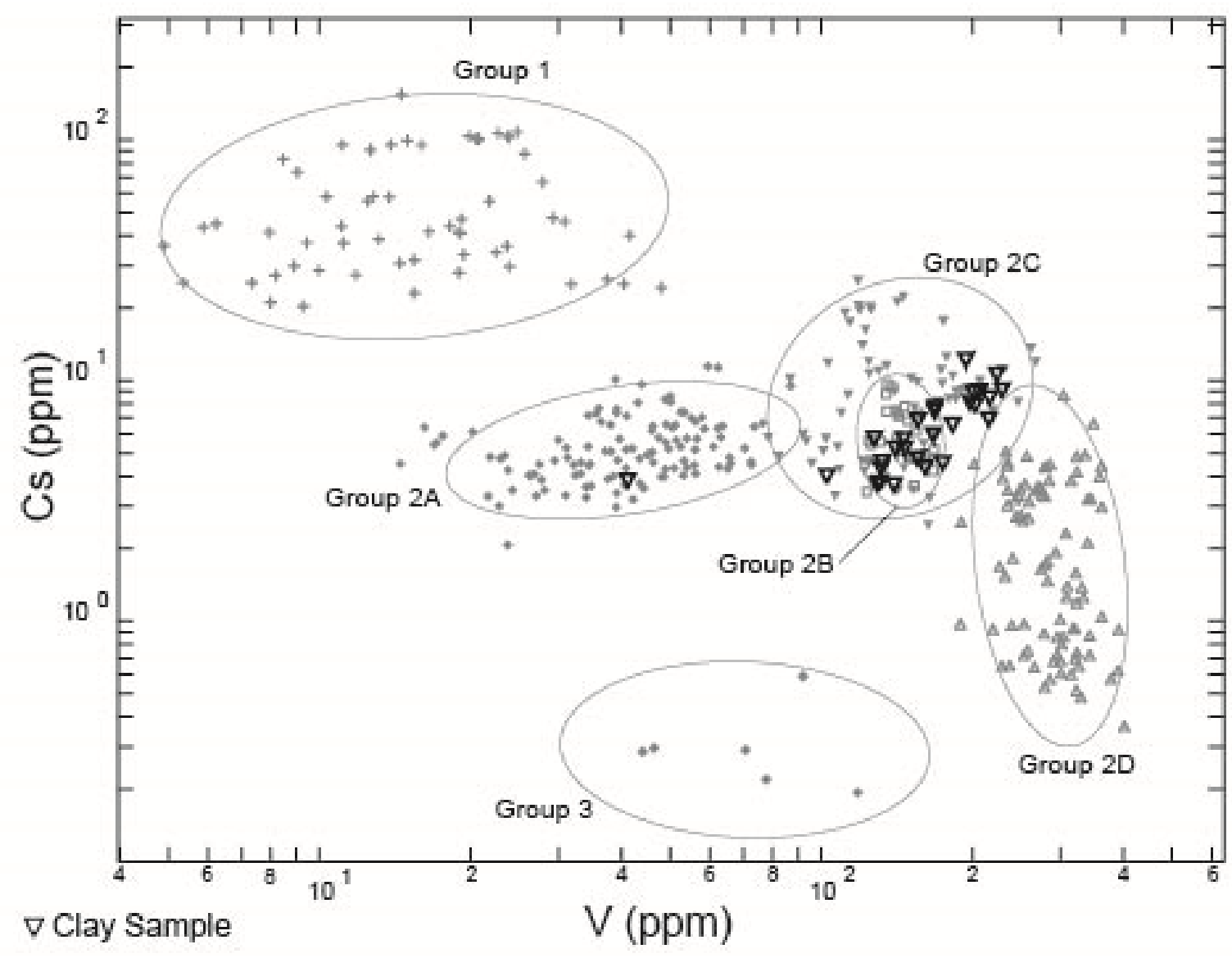

204 Figure 5. Bivariate plot of Cs versus V concentrations in the northwestern Alaska ceramic 206 dataset showing geological clay specimens (labeled) grouped within Group 2c. Ellipses are 207 drawn at the $90 \%$ confidence interval.

208

209

210 
211 Table 7. Locations and Analytical IDs for Clay and Temper Materials (letters correspond to 212 Figure 6)

\begin{tabular}{lllll} 
& & Location & Clay & Temper \\
\hline Coast & & & & \\
& A & $\begin{array}{l}\text { Cape Espenberg } \\
\text { Kotzebue Sound }\end{array}$ & SLA367 & SLA368-371 \\
& B & SLA431-433 \\
& C & $\begin{array}{l}\text { Cape } \\
\text { Krusenstern }\end{array}$ & SLA427 & SLA428-430
\end{tabular}

Lower Kobuk River

D Lower Kobuk SLA392-393 SLA453-455

Middle Kobuk River

$\begin{array}{llll}\text { E } & \text { Ahteut } & \text { SLA391 } & \text { SLA452 } \\ F & \text { Onion Portage } & \text { SLA390 } & \text { SLA450 }\end{array}$

Upper Kobuk

\begin{tabular}{|c|c|c|c|c|}
\hline & G & Kobuk Village & $\begin{array}{l}\text { SLA380-383, } \\
\text { SLA388 }\end{array}$ & SLA442-444 \\
\hline & $\mathrm{H}$ & Mauneluk & SLA378-379 & $\begin{array}{l}\text { SLA441, } \\
\text { SLA448 }\end{array}$ \\
\hline & I & Pah River & SLA376-377 & SLA439-440 \\
\hline & $\mathrm{J}$ & Shungnak & $\begin{array}{l}\text { SLA384, 386, } \\
387\end{array}$ & SLA445-446 \\
\hline \multicolumn{5}{|l|}{ Interior } \\
\hline & $\mathrm{K}$ & Imuruk Lake & SLA372-375 & SLA437-438 \\
\hline
\end{tabular}

213

214 

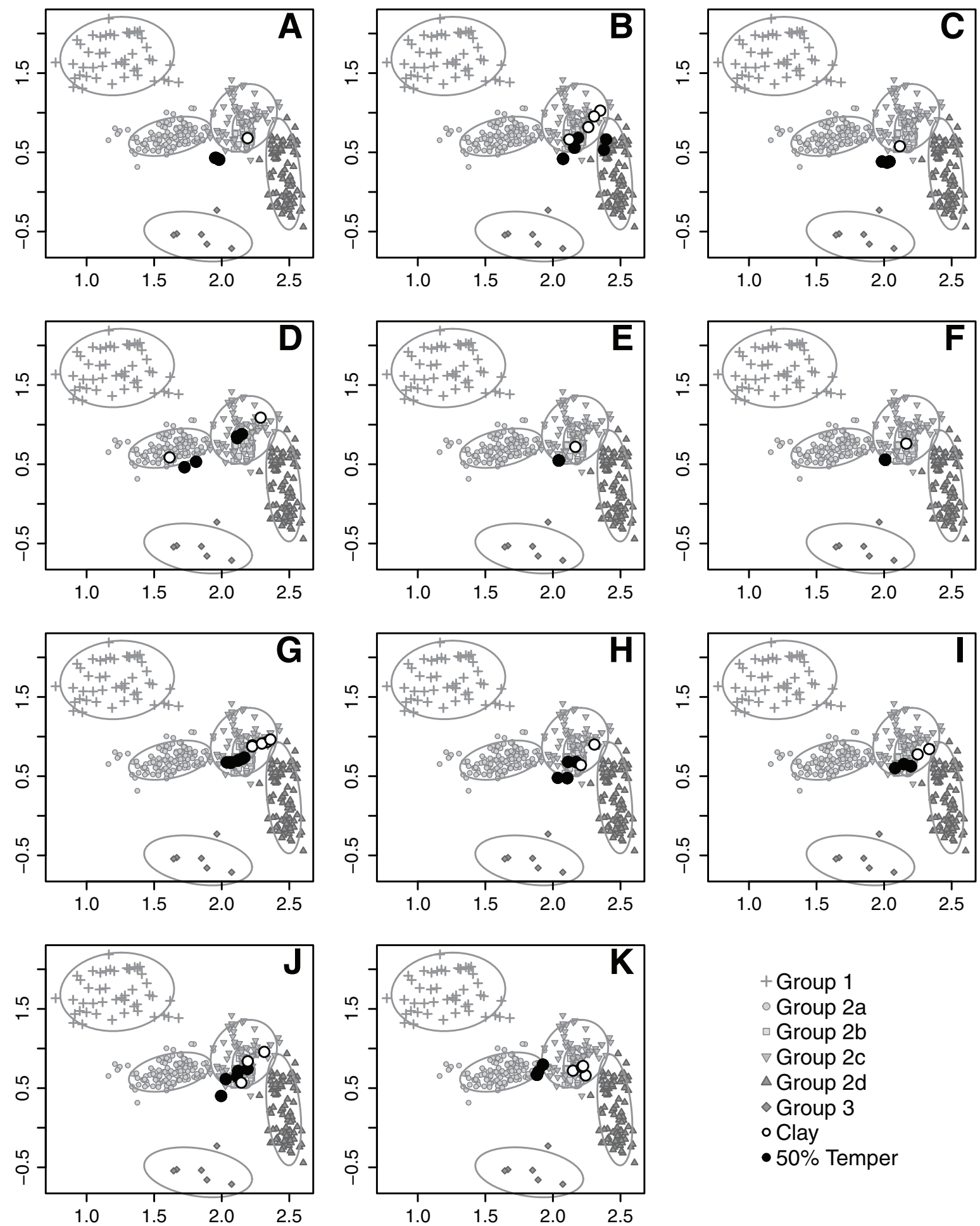

+ Group 1

- Group 2a

$\square$ Group 2b

$\nabla$ Group 2c

$\triangle$ Group 2d

$\diamond$ Group 3

- Clay

- $50 \%$ Temper

216 Figure 6. Log-log plot of Cs and V showing ceramic compositional groups, raw clays (white

217 circles), and modeled ceramic compositions with 50\% temper (black circles). A: Cape Espenberg;

218 B: Kotzebue Sound; C: Cape Krusenstern; D: Lower Kobuk; E: Ahteut; F: Onion Portage; G: Kobuk 
219 Village; H: Mauneluk; I: Pah River; J: Shungnak; K: Imuruk Lake. Confidence ellipses are drawn

220 at the $90 \%$ confidence interval. Note that only two dimensions are shown here. Multivariate

221 probabilities for each raw clay and for modeled ceramic compositions are provided in the

222 Supplementary Material.

223

$224 \quad 6.0$ Discussion

2256.1 Clay Character

226 The results of clay geochemical analysis indicate that clays across the region, more than

$22725,600,000$ acres in size, are remarkably homogenous. This is surprising, given that samples

228 were collected from a variety of depositional contexts (e.g., glacial, lacustrine, colluvial). In

229 addition, processes of ceramic production (e.g., treatment of clay, addition of temper) and

230 postdepositional processes (e.g., weathering, leaching/enrichment of elements and minerals)

231 can alter the chemical composition of pottery so that the analytically determined compositions

232 of ceramic artifacts may not necessarily appear to be statistically strong matches to geological

233 clays. Analyses of clays and clay-rich sediments from the region suggest greater heterogeneity

234 in clays than indicated by the bulk geochemical analyses reported here. For example, analyses

235 of sediments associated with thermoluminescence-dated ceramics yielded variable

236 measurements for ${ }^{238} \mathrm{U},{ }^{233} \mathrm{Th}$, and $\mathrm{K}$ (Feathers 2011). X-ray diffraction (XRD) of four clay

237 specimens (SLA 364, 369, 372, 389) from across the region indicates some variation in

238 mineralogical composition (Table 8) though additional analysis is needed (Perkins 2012). Illite,

239 chlorite, and albite tend to be enriched in Al, whereas dolomite and calcite are Ca-enriched. All

240 of the clay specimens subjected to XRD contain some amount of Al-rich feldspar (albite) and Al-

241 bearing phyllosilicate (illite), although the amount is undetermined th this time. INAA indicates

242 that all the sampled clays have approximately the same concentrations of Al, and XRD analysis

243 indicates that all the clays contain Al-bearing minerals. Thus, the XRD and INAA are in

244 congruence to some degree, although XRD analysis indicates greater heterogeneity in clay

245 composition than the INAA. XRD analysis of SLA 372 from the southern study area indicates that

246 clays in this region are somewhat enriched in Al. While Groups 1 and 2 ceramics show some

247 enrichment in Al, Group 3 ceramics are significantly depleted in Al; the results of XRD analysis

248 further indicate that the Group 3 ceramics may be nonlocal in origin. Additional mineralogical

249 analysis is necessary to test this hypothesis.

250 
251 Table 8. XRD results for Four Clay Samples

Clay Sample Minerals identified

\begin{tabular}{lll}
\hline SLA 364 & Illite, plagioclase albite, chlorite & North \\
SLA 369 & Illite, chlorite, plagioclase albite, calcite, & Central \\
& dolomite & \\
SLA 389 & Illite, chlorite, calcite, dolomite, plagioclase & Central \\
& albite & \\
SLA 372 & Sanidine, chlorite, plagioclase albite, illite & South
\end{tabular}

252

Ultimately, the analysis of clays proved to be of limited usefulness in linking ceramic

254 geochemical groups to geological source areas at the fine scales as initially hoped; yet, the clay

255 analyses do tell us something about production practices. The ceramic groupings identified in

256 this study are based primarily on the paste recipes used by potters, which did have some

257 regional variation based on the distribution of different geochemical groups across the region.

258 Clay and temper modeling further support this conclusion, indicating that people did not

259 frequently use the mineral material (typically beach or river sand) located adjacent to the clay

260 sources to temper their ceramic materials. Rather, people may have taken advantage of the

261 natural tempering of clay deposits and added little or no additional mineral temper to the

262 ceramics. The geochemical similarity between the clays and the majority of the ceramics (those

263 in Group 2c) suggests that little mineral material was added to clays. If mineral temper was

264 added, modeling indicates that the mineral temper they included was not collected in proximity

265 to the sampled clay deposits. Furthermore, the low group probabilities for modeled

266 combinations of Cape Espenberg clays and tempers suggests that people were not procuring

267 ceramic raw materials in this location. The absence of modeled compositions resembling Group

2681 or 3 suggests that ceramics from these groups may originate outside study area.

269

270

\subsection{Ceramic Production Regions}

$271 \quad$ Clay and ceramic geochemical analysis did identify several production regions. Most of

272 the ceramic specimens fall into what we have referred to as Macrogroup 2 and its various

273 subgroups. Group 2a samples were most common at central Kobuk and central Noatak sites

274 (Ahteut and Maiyumerak, respectively), suggesting production in one or both of these locales

275 and/or interaction between people living in these areas (Figure 7); there are several

276 ethnographically known travel routes between the two river systems (Burch, 2005:282-285) 
277 that may have been used in the past as well. Clay sample SLA 393 from the lower Kobuk is

278 associated with this group, however, which makes it difficult to draw any more specific

279 conclusions about the source locale of Group 2a. Group $2 \mathrm{~b}$ is relatively rare and is most

280 abundant in the vicinity of the Kotzebue site; thus, we suggest that ceramics in this group likely

281 originated at or near Kotzebue. Group 2c ceramics are most abundant along the north coast and

282 at central Kobuk river sites. These likely originated somewhere in the north-central region. In

283 addition, because all of the clay samples except SLA 393 cluster within this group, Group 2c

284 ceramics could represent unmodified use of regional clays. Group $2 \mathrm{~d}$ ceramics are most

285 abundant at southern sites and probably originated in this region.

286

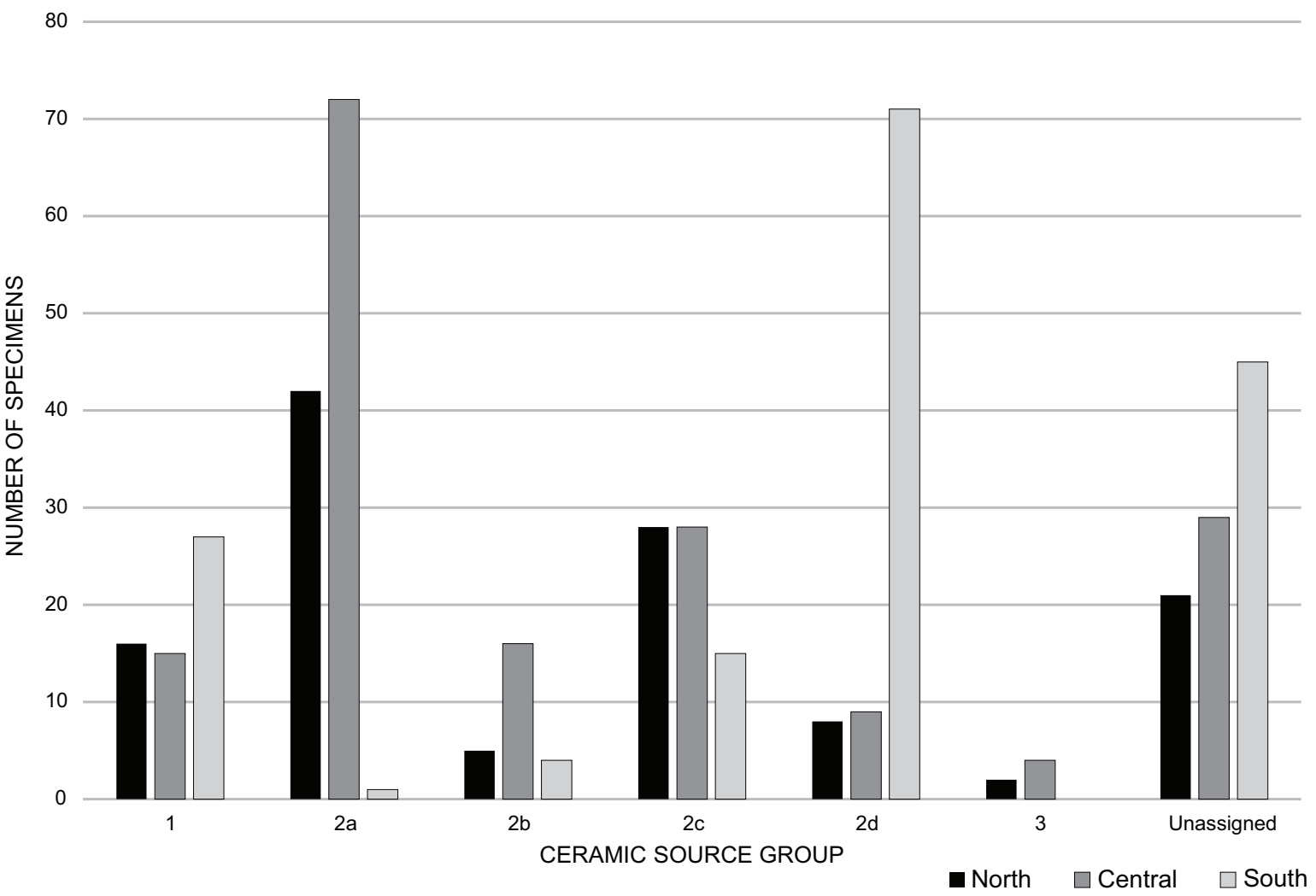

Figure 7. Source group abundance in each sub-region of the study area.

Group 1 and 3 ceramics are present in small numbers at several sites. At this point it is difficult to determine the origin of these ceramics with any certainty. Group 1 ceramics show

293 Kiana area of lower Kobuk (Swenson, 2012; Warner, 1985). Specimens assigned to Group 1 are 
294 present at sites from both these regions, but they are proportionally most abundant in Lopp

295 Lagoon sites in the south. Group 1 is therefore tentatively assigned to the southern region, 296 though additional analyses may show that Group 1 materials originated outside the study area.

297 None of the modeled clay/temper samples are similar to Group 1, further suggesting that these

298 may have come from outside the Kotzebue Sound region. Group 3 comprises only five ceramic

299 specimens, and these too may have originated from outside the region. Group 3 specimens

300 were found at the Cape Krusenstern site complex (1 out of 50 specimens from the site) and the 301 Ambler Island site, located in the middle/upper Kobuk River (4 of 16 specimens from the site).

302 Given the relatively large Cape Krusenstern ceramic data set it seems unlikely that the rarity of

303 Group 3 ceramics is due to sampling issues at the site complex. None of the modeled

304 clay/temper samples are similar to Group 3.

305

\subsection{Conclusions}

Analysis of an expanded ceramic data set more firmly establishes the ceramic geochemical groups identified by the pilot study (Anderson, et al. 2011). The original three macrogroups (1-3), three subgroups of Macrogroup 2 (2a-2c), and Macrogroup 1 and 2 outliers are now consolidated into three macrogroups (1-3), four subgroups of Macrogroup 2 (2a-2d),

311 and specimens that cannot be assigned to any of these macrogroups or subgroups. The addition

312 of clay and temper samples collected during a raw-material survey was informative, although

313 not in the manner anticipated. Though clay and tempering materials were collected over a

314 broad area, the clay specimens demonstrated remarkable geochemical homogeneity, as all but

315 one clay specimen groups with Macrogroup 2c. This suggests that potters added little to no

316 mineral temper to the clays and also that Macrogroup 2c ceramics were produced and

317 distributed from the north and central areas of northwest Alaska to the south. Group 1 and 3

318 ceramics might be evidence of pottery having been brought into the region from elsewhere.

319 Results suggest the possibility of areas of greater production (e.g., the central Kobuk River)

320 perhaps due to an abundance of clay or wood fuels for ceramic firing.

Overall, it is apparent that ceramics circulated widely around the region over time. This

323 work lays the foundation for further exploring the cultural processes that underlie these

324 distributions. A comparison of ceramic stylistic distribution patterns and geochemical groups is

325 forthcoming. Analysis of ceramic and raw material mineralogy will also further inform this 
326 study. Ceramic petrography may be of particular use in refining our understanding of the nature 327 of inclusions present within ceramic sherds. This study of northern Alaskan ceramic production

328 locales provides insight into the complexities of hunter-gatherer ceramic production and 329 distribution.

330

331 


\section{Acknowledgments}

333

334 Thank you to the Bureau of Land Management, U.S. Fish and Wildlife Service, National Park

335 Service (NPS), and Northwest Alaska Native Association for permission to conduct research on

336 agency and organization lands. This research was funded by a National Science Foundation

337 (NSF) Dissertation Improvement Grant (NSF ARC-0936696), the Cape Espenberg Project (NSF

338 ARC-0755725), a NPS Murie Science and Learning Fellowship, and the Lewis and Clark Fund

339 Fellowship from the American Philosophical Society American Philosophical Society. Research at

340 the MURR Archaeometry Laboratory is supported in part by a grant from the National Science

341 Foundation (NSF 1415403). We thank Erica Murren and Cody Roush for their assistance in the

342 MURR analyses. Johanna Shea created the figures and Rihannon Held provided technical

343 editing.

344

345 


\section{References Cited}

347 Ackerman, R. E.

3481982 The Neolithic-Bronze Age Cultures of Asia and the Norton Phase of Alaskan

\section{Adams, J. A.} 1977 Archeological Excavations at Cloud Lake Village: An Early Nineteenth Century Eskimo Village on the Seward Peninsula. University of Wisconsin, Madison.

Anderson, S. L., M. T. Boulanger, and M. D. Glascock

2011 A new perspective on Late Holocene social interaction in Northwest Alaska: results of a preliminary ceramic sourcing study. Journal of Archaeological Science 38(5):943-955.

Anderson, S. L. R. 2011 From Tundra to Forest: Ceramic Distribution and Social Interaction in Northwest Alaska. Ph.D. dissertation, Department of Anthropology, University of Washington, Seattle.

Anderson, S. L. R. accepted Clay Source Provenance Survey in Remote Areas of Northwest Alaska: Late Holocene Ceramic Production in the Arctic. Journal of Field Archaeology.

Baxter, M. J. and C. E. Buck 2000 Data handling and statistical analysis. In Computer Applications and Quantitative Methods in Archaeology, 1991, edited by G. Lock and J. Moffet, pp. 141-148. Vol. S577. BAR International Series, Oxford.

Bieber, A. M. J., D. W. Brooks, G. Harbottle, and E. V. Sayre 1976 Application of Multivariate techniques to analytical data on aegean ceramics. Archaeometry 18:59-74.

Bishop, R. L. and H. Neff 1989 Compositional Data Analysis in Archaeology. In Archaeological Chemistry IV, edited by R. O. Allen, pp. 576-586. Advances in Chemistry. Vol. 220. American Chemical Society, Washington, D.C.

Burch, E. S. J. 2005 Alliance and Conflict: The World System of the Inupiaq Eskimos. University of Nebraska Press, Lincoln.

Darwent, J., O.K. Mason, J.F. Hoffecker, and C.M. Darwent 2013 1,000 Years of House Change at Cape Espenberg, Alaska: a Case Study in Horizontal Stratigraphy. American Antiquity 78(3):433-455

Eerkens, J. W. 
2001 The origins of pottery among late prehistoric hunter-gatherers in California and the western Great Basin. Ph.D. dissertation, Department of Anthropology, University of California Santa Barbara, Santa Barbara.

2002 Ceramic Production among Small-Scale and Mobile Hunters and Gatherers: A Case Study from the Southwestern Great Basin. Journal of Anthropological Archaeology 21:220-229.

2003 Residential mobility and pottery use in the Western Great Basin. Current Anthropology 44(5):728-738.

Eerkens, J. W., H. Neff, and M. D. Glascock

2002 Ceramic Production among Small-Scale and Mobile Hunters and Gatherers: A Case Study from the Southwestern Great Basin. Journal of Anthropological Archaeology 21:200-229.

Feathers, J.

2011 Luminescence Analysis of Ceramics from Northwest Alaska. University of Washington Luminescence Dating Laboratory, Seattle.

Frink, L. and K. Harry 2008 The Beauty of "Ugly" Eskimo Cooking Pots. American Antiquity 73(1):103-118.

Giddings, J. L.

1952 The Arctic Woodland Culture of the Kobuk River. University Museum Monograph. University of Pennsylvania, Philadelphia.

Giddings, J. L. and D. D. Anderson 1986 Beach Ridge Archeology of Cape Krusenstern: Eskimo and Pre-Eskimo Settlements around Kotzebue Sound, Alaska. Publications in Archeology 20. National Park Service, Washington, D.C.

Gilbert-Young, $\mathrm{S}$. 2004 The Archaeology of a Severely Vandalized Site, 49-Mis-032, at Lake Kayak, Noatak National Preserve, Northwest Alaska. MA thesis, Washington State University.

Glascock, M. D. 1992 Characterization of archaeological ceramics at MURR by neutron activation analysis and multivariate statistics, in Neff 1992. In Chemical characterization of ceramic pastes in archaeology, edited by H. Neff, pp. 11-26. Monographs in New World Archaeology 7. Prehistory Press, Madison.

Glascock, M. D. and H. Neff 2003 Neutron activation analysis and provenance research in archaeology. Measurement Science \& Technology. 14:1516-1526.

Harbottle, G. 1976 Activation analysis in archaeology. Radiochemistry 3(1):33-72. 
Harritt, R. K. 1994 Eskimo Prehistory on the Seward Peninsula. U.S. National Park Service, Alaska Region Resources Report NPS/ARORCR/CRR-93/212, Anchorage.

Jordan, P. and M. Zvelebil 2009 Ceramics before farming : the dispersal of pottery among prehistoric Eurasian hunter-gatherers. Left Coast Press, Walnut Creek.

Neff, $\mathrm{H}$.

2000 Neutron Activation Analysis for Provenance Determination in Archaeology. In Modern Analytical Methods in Art and Archaeology, edited by E. Ciliberto and G. Spoto, pp. 81-134. Chemical Analysis, Vol. 155, Windefordner, general editor. WileyInterscience, New York.

Neff, H., R. L. Bishop, and E. V. Sayre 1988 A simulation approach to the problem of tempering in compositional studies of archaeological ceramics. Journal of Archaeological Science 15:159-172.

Perkins, R. B. 2012 Report on X-Ray Diffraction Analysis of Four Clay-Rich Samples. Portland State University, Portland.

Powers, W. R., J. Adams, A. Godfrey, J. Ketz, D. Plaskett and G. R. Scott 1982 The Chukchi-Imuruk Report: Archeological Investigations in the Bering Land Bridge National Preserve, Seward Peninsula, Alaska, 1974 and 1975. Anthropological and Historic Preservation Studies Unit Occasional Paper 31. University of Alaska, Fairbanks.

Quinn, P., M. Burton, D. Broughton, and S. Van Heymbeeck 2013 Deciphering Compositional Patterning in Plainware Ceramics from Late Prehistoric Hunter-Gatherer Sites in the Peninsular Ranges, San Diego County, California. American Antiquity 78(4):779-789.

Rice, P. M. 1987 Pottery Analysis: A Sourcebook. The University of Chicago Press, Chicago and London.

Schaaf, J. (editor) 1988 The Bering Land Bridge: An Archaeological Survey. 14. National Park Service, Anchorage.

Shirar, S.

2007 Maiyumerak Creek: Late Prehistoric Subsistence and Seasonality in Northwest Alaska. MA thesis, University of Alaska - Fairbanks.

2011 Late Holocene Chronology of the Noatak and Kobuk Rivers. Alaska Journal of Anthropology 9(2):1-16. 
Simms, S. R., J. R. Bright, and A. Ugan

490

491

492

493

494

495

496

497 1997 Plain-Ware Ceramics and Residential Mobility: A Case Study from the Great Basin. Journal of Archaeological Science 24:779-792.

Swenson, B.

2012 Alaska Strategic and Critical Minerals Potential and Assessment. Paper presented at the Strategic and Critical Minerals Summit, Fairbanks, November 30.

498

499

500

501

502

503

Warner, J. D. 1985 Critical and Strategic Minerals in Alaska: Tin, Tantalum, and Columblum. U.S. Department of Interior Bureau of Mines, Washington, D.C.

Young, C. E. 2000 The Archaeology of Agiagruat (49noa217), Cape Krusenstern National Monument, Northwest Alaska. MA thesis, Washington State University. 